\title{
Energy Essential in the Industrial Manufacturing in Malaysia
}

\author{
Hussain Ali Bekhet \\ Graduate Business School, College of Graduate Studies \\ Universiti Tenaga Nasional (UNITEN), Malaysia \\ E-mail: Profhussain@uniten.edu.my or drbekhet1953@hotmail.com \\ Nor Hamisham Binti Harun \\ Department of Finance \& Economics, College of Business Management and Accounting \\ Universiti Tenaga Nasional (UNITEN), Muadzam Shah Campus, Pahang, Malaysia \\ E-mail: Hamisham@uniten.edu.my
}

Received: August 3, 2011

Accepted: August 29, 2011

Published: January 1, 2012

doi:10.5539/ijef.v4n1p129

URL: http://dx.doi.org/10.5539/ijef.v4n1p129

\begin{abstract}
The purpose of this paper is to examine the causality relationship between production and energy of industrial manufacturing in Malaysia. Time series data for production $(\mathrm{Q})$, capital $(\mathrm{K})$, labour $(\mathrm{L})$ and energy $(\mathrm{E})$ for the 1978-2009 period, are applied. However, production theory was used to explore the characteristics of the capital, labour and energy within time series procedures. The results of the ADF and PP tests show that all variables are stationary in the first differences, except for energy, which is stationary at second differences. Meanwhile, all variables are cointegrated at $1 \%$ significance level using CRDW test. Results show that there is unidirectional causality in the long run running from energy to the production. Therefore, energy plays an important role in the production of industrial manufacturing in Malaysia. No significant relationship between all variables appears to be in the short run.
\end{abstract}

Keywords: Energy, Production theory, Manufacturing Industrial, Causality, Malaysia

\section{Introduction}

Currently, the major globalization issue that isoften discussed is about energy. Energy economics is a field that studies human utilization of energy resources and energy commodities and consequences of that utilization (Sweeney, 2000). Over the last three decades, the demand for energy in Malaysiawitnessed a noticeable growth, as policies were practised towards greater economic growth and social development. However, the debt amount burden coincidedwith the high cost of energy which has large economic and financial implications for the country's capacity to achieve its goals in the short and long terms.

Against this background, the government of Malaysia has begun to place greater focus on energy conservation and renewable energy sources. It has designed a course of action "called the Small Renewable Energy Power Programme (SREP)". The objectives of this programme are 1) to promote and encourage the use of renewable energy for grid connected power generation system; 2) to reduce the dependency on oil and 3) to minimize the negative impact on the environment.

It is important, therefore, to find out whether there is a causal link between energy and economic growth, given that any constraints placed on energy consumption would have an adverse effect on growth and development if causality runs from energy to GDP only. Numerous studies have exploredthe causal relationship between energy and economic growth.Many researchers used time series data to test the existence and direction of causality between energy consumption and GDP in the various countries (Lorde (2010), Chandran (2010), Stern (2000), Jumbe (2010), Belloumi (2009) and Ghali (2004).

However, only few papersdiscuss the relationship between production growth and energy in manufacturing industrial, particularly in Malaysia. Most of these papershave general discussion in various countries but not as much of focus in detail for various sectors. Besides, this study aims to find out whether this energy constitutesa factorinfluencing production growth or vice versa, focusing in industrial manufacturingin Malaysia. 
Therefore, the primary aim of the current paper is to examine the existence of a long run equilibrium relationship between production and independent variables, using a CRDW test. It also aims atmeasuring short run and long run causal relationship in the manufacturing industrial, case study of Malaysia.

At present, the industrial manufacturingis the second largest contributor in Malaysia's GDP, contributingby 25.87\%, $26.92 \%$ and $27.14 \%$ in year 2009, 2010 and 2011 respectively. Even though, this industrial is very vital for expandingproduction. This is because most products are produced in a manufacturing industrial, such as rubber industry, food industry, petroleum sector, heavy industry and chemical industry. Thus, the study of the causal relationship between production and energy will facilitatetheunderstandingof the role of energy for the industrial manufacturingin Malaysian economic growth. The results of the causality test are useful for policy makers to plan whether to raise or reduce the energy use for industrial manufacturingfor the future.

The remainder of this paper is organized as follows. Section 2 examines the growth rate of industrial manufacturingin Malaysia. Section 3 reviews previous literature related to the current study. Section 4 defines the data, variables and methodology used in this study. Section 5 presents the result and analysis. Also analyzes causal relationship between production and energy. In Section 6, we discuss the policy implications of the results. Finally, section 7 summarises some conclusions, recommendations and further studies.

\section{Overview of Industrial manufacturing in Malaysia}

Manufacturing industries in Malaysia have been significantly contributing to the country's economy since 1960. During the colonial period, the country was a major producer of raw materials, namely tin and rubber. Currently, the industrial manufacturingis a dynamic and flourishing component of the national economy.Malaysia has progressed from being an assembler of a wide range of electrical and machinery goods to manufacturing by the year 1980 .

Malaysia has established a diverse and fast growing industrial manufacturingthat plays aleading role in the Malaysian economy. Since 1970, the proportion of GDP provided by the industrial manufacturingin Malaysia has grown from $20.2 \%$ in 1979 to around $29 \%$ in 1999. In year 2010, Malaysian economic growth rate was $7.2 \%$.

The United States continues to be the single largest foreign investor in Malaysia's manufacturing industrial, with approved new manufacturing investments totalling US $\$ 1.37$ billion (RM5.2 billion) in 1999. The major investment projects were in the chemical, electronics and electrical industries.

Figure 1 shows that the growth rate of industrial manufacturingproduction for the 1978-2009 period was 13\%. The main source of this production was coming from the rubber industry, food industry, petroleum sector, heavy industry, the chemical industry and others.

Even though, the industrial manufacturinghad high linkages with the other sectors that influenced its production (Bekhet, 2010). This relationship depended on high demand factor for the energy, capital and labour. Figures 2, 3 and 4 indicate that a growth rate of energy use in the industrial manufacturingis $7 \%$ compared to other factors, capital (6\%) and labour (5\%), respectively.

Thehighest growth rate of energy compared to the other factors show that, the demand for energy is increasing annually. This situation indicates that usage of energy is eventually growing for the production of industrial manufacturingin Malaysia. Accordingly, energy in Malaysia is consumed mainly by the transportation and industrial sectors including manufacturing, construction and mining, $40.5 \%$ and $38.6 \%$ respectively (Zaini, no date).

The energy of industrial manufacturingis generated by a combination of fossil fuel and renewable energy, such as coal, oil, gas, hydropower, and biomass and wind power. In 2005, the fuel mix consisted of $62.7 \%$ petroleum product, $19 \%$ hydroelectric power, $15.1 \%$ natural gas, $3.2 \%$ coal and coke. Thus, the greatest percentage of the Malaysian fuel mix is related to petroleum products.

However, the current debate in Malaysia isfocused on the scarcity of energy resources and the energy efficiency. For this reason, the government tries to increase the renewable energy and determination on how the usage of this energy also reduces the negative impact to the environment. Then, the analysis will become interesting to establish the empirical study on the importance of the energy towards the production, of theindustrial manufacturingin Malaysia.

\section{Literature Review}

Most of studies examining the relationship between energy use and economic growth for the various countries using time series data, show two different findings: either unidirectional or bidirectional. Lord et al. (2010), revealed a bidirectional causal relationship between electrical energy consumption and real GDP in the long run, but only a unidirectional causal relationship from energy to output in the short run. 
Chandran et al. (2010) show that, in the short run, there is a unidirectional causal flow from electricity consumption to economic growth in Malaysia. This result is similar to that of Lord et al. (2010). But for the alternative country, samples hardly affect the causality relationship, particularly in a multivariate multi-sector framework (Costantini, 2010).

Jumbe (2010) investigated the causality between electricity consumption and GDP in Malawi. The results detected bi-directional causality between electricity consumption and GDP, suggesting that electricity consumption and GDP are jointly determined. Yang (2000) also found the same result in Taiwan. Hedis covered bi-directional causality between total energy consumption and GDP. It was also revealed that different directions of cause existed between GDP and various kind of energy consumption.

Furthermore, Ya-qun et al. (2008) explained bi-directional causality between gross energy consumption and GDP of China for the 1978-2006 period. Yet, Shiu et al. (2004) analyzed the same country and used data for the year 1971-2000 period. The results indicated that there is a Granger causality running from electricity consumption to real GDP in China but not vice versa.

Belloumi (2009) investigated the causal relationship between per capita energy consumption (PCEC) and per capita gross domestic product (PCGDP) in Tunisia. The results showed a long run bi-directional between PCGDP and PCEC and uni-directional causality from energy to GDP.However, in case of Bangladesh, Mozumder et al. (2007) found that per capita electricity consumption did not cause per capita GDP.

Analysis in Canada using VEC specification, the short run dynamics of variables indicated that Granger Causality is running in both directions (bi-directional) between output growth and energy use (Ghali, 2004). Jamil and Ahmad (2010) examined the relationship among electricity consumption, its price and real GDP at the aggregate and sectoral level in Pakistan. The results showed the presence of uni-directional causality from real economic to electricity consumption.

Narayan et al. (2009) used multivariate granger causality between electricity consumption, exports and GDP in the Middle Eastern countries. The results show that there were statistically significant feedback effects between these variables. If $1 \%$ increases in electricity consumption will influencethe GDP increases by $0.04 \%$. Whereas exports increase by $1 \%$ affect GDP increases by $0.17 \%$. The increases GDP by $1 \%$ generate the electricity consumption increases by $0.95 \%$.

On the other hand, the analysis used an ARDL approach implying that real output and employment werea long runrelationship with the disaggregate energy consumption (Sari et al., 2008). In the case of Asian developing countries, they have different results from various countries to show the causal relationship between energy consumption and income for India, Indonesia, Philippines and Thailand (Asafu-Adjye, 2000).

The other analysis using Granger Causality to refer to the manufacturing sector, only focuses on the factors of production. Soytas (2007), examined the relationship between energy and production in Turkish manufacturing industry. The results show uni-directional causality running from electricity consumption to value added.

However, the current study focuses on the production theory to examine the presence of the long run equilibrium relationshipand causal relationship- short run and long run -between production and energy in the industrial manufacturingin Malaysia.These results will help policymakers get better information for policy formulation.

\section{Data and Methodology}

\subsection{Data and Variables}

This study used time series data for the industrial manufacturingfor the 1978-2009 period. It uses production, energy, capital and labour to representthe variables. The production and two inputs of variables (capital and labour) are extracted from Department of Statistics Malaysia (2009) and data for energy is taken from National Energy Balance in Malaysia. The clarifications of these variables are:

Q gross output in value RM ' 000 .

E total energy in industry in kilo tones of oil equivalent (ktoe) .

K gross fixed capital formation at constant price (2000 as a base year).

$\mathrm{L}$ total number of workers in manufacturing industrial.

Technology $(\mathrm{T})$ is included as a variable, indicating that when time is increased, the new technology will be introduced. The E-Views Microsoft package was used to achieve the objectives of this paper. 


\subsection{Methodology}

In the current paper, production theory is used which was presented by Stern (1993) and presently advanced by Ghali and El-Sakka (2004), Soytas and Sari (2007) and Yuan et al. (2008). Currently, the framework that we applied as follows:

$$
Q=A(t) K^{\propto} L^{\beta} E^{\gamma}
$$

Where $\mathrm{Q}$ is the production, $\mathrm{t}$ is technology, $\mathrm{K}$ is capital, $\mathrm{L}$ is labour and $\mathrm{E}$ is energy. The estimated coefficients $\alpha, \beta$, $\gamma$ are represents the elasticities of capital, labour and energy, respectively.

For the purpose of this study, we can rewrite the Equation [1] by using a logarithms form, as shows in Equation (2).

$$
\operatorname{In} Q=\operatorname{In} A(t)+\propto \operatorname{In} K+\beta \operatorname{In} L+\gamma \operatorname{In} E
$$

The parameters $\alpha, \beta$ and $\gamma$ represent the elasticities of capital, labour and energy respectively. We used the unit root test and multivariate co-integration test for the long run equilibrium among the variables. To examine the short run and long run causal relationship between the variables, we used the VECM.

\subsubsection{Unit Root Test}

As a result of the importance of stationary properties, Augmented Dickey-Fuller (ADF) and Phillips-Perron (PP) tests are applied to find the existence of unit roots and robustness in each of the variables. The purpose of these tests is to make sure that the individual variables used in this study are stationary and to determine whether they are integrated or not. The result could be spurious regression, if the test is non-stationary series. The null and the alternatives hypothesis for the existence of unit root for variable $\mathrm{X}_{\mathrm{i}}(\mathrm{K}, \mathrm{L}$ and $\mathrm{E})$ are;

$\mathrm{H}_{0}: \delta=0\left(\mathrm{X}_{\mathrm{i}}\right.$ isnon-stationary or contains a unit root $)$

$\mathrm{H}_{1}: \delta<0\left(\mathrm{X}_{\mathrm{i}}\right.$ is stationary or non unit root $)$

Then, if the value of ADF or PP tests statistic is less than critical value, the null hypothesis will be rejected. In other words, if the estimated value for $\delta$ is significantly less than zero, the series is stationary. Otherwise, the time series have a unit root process. Some studies confirmed that, the economic variables are likely to be stationary in the first difference, $I(1)$, for most economic variables (Tang, 2009).

\subsubsection{Co-integration Test}

The co-integration procedure is used to identify the long run relationship between the dependent and independent variables.We use the simplest test method using Durbin Watson (DW) test statistics called Cointegrating Regression Durbin Watson (CRDW), (Cromwell et al.,1994). This test is used to determine if the residuals from equation (2) appear to be stationary or not. The null hypothesis will be accepted if the DW value is zero or the DW value is more than critical value. Alternatively, the null would be rejected if the DW value is large or the DW value is less than the critical value, indicating the existence of cointegration.

$\mathrm{H}_{0}$ : $\mathrm{DW}=0$ or $\mathrm{DW}>\mathrm{DF}$ (cointegration does not exist)

$\mathrm{H}_{1}: \mathrm{DW}=0$ or $\mathrm{DW}<\mathrm{DF}$ (cointegration does exist)

\subsubsection{Vector Error Correction and Granger Causality}

The existence of co-integration implies Granger causality, but does not point out to the direction of causality. In order to assess the direction, we employ a vector error correction (VECM). The VECM enables us to estimate the long run and short run Granger causality (Bekhet \& Othman, 2011). It is used for correcting disequilibrium and testing for long run and short run causality among cointegrated variables. Moreover, the short run causality is to bring the lost information due to differencing back into the system through the error correction terms (Soytas and Sari, 2003). We can estimate a VEC model for the Granger causality test, as follows:

$$
\begin{aligned}
& \Delta \ln Q_{t}=\mu_{0}+\sum_{i=1} \theta_{0} \Delta \ln Q_{t-1}+\sum_{i=1} \alpha_{0} \Delta \ln K_{t-1}+\sum_{i=1} \beta_{0} \Delta \ln L_{t-1}+\sum_{i=1} \gamma_{0} \ln E_{t-1}+\partial_{0} e c t_{t-1}+e_{t 1} \\
& \Delta \ln K_{t}=\mu_{1}+\sum_{i=1} \theta_{1} \Delta \ln Q_{t-1}+\sum_{i=1} \alpha_{1} \Delta \ln K_{t-1}+\sum_{i=1} \beta_{1} \Delta \ln L_{t-1}+\sum_{i=1} \gamma_{1} \ln E_{t-1}+\partial_{1} e c t_{t-1}+e_{t 2} \\
& \Delta \ln L_{t}=\mu_{2}+\sum_{i=1} \theta_{2} \Delta \ln Q_{t-1}+\sum_{i=1} \alpha_{2} \Delta \ln K_{t-1}+\sum_{i=1} \beta_{2} \Delta \ln L_{t-1}+\sum_{i=1} \gamma_{2} \ln E_{t-1}+\partial_{2} e c t_{t-1}+e_{t 3} \\
& \Delta \ln E_{t}=\mu_{3}+\sum_{i=1} \theta_{3} \Delta \ln Q_{t-1}+\sum_{i=1} \alpha_{3} \Delta \ln K_{t-1}+\sum_{i=1} \beta_{3} \Delta \ln L_{t-1}+\sum_{i=1} \gamma_{3} \ln E_{t-1}+\partial_{3} e c t_{t-1}+e_{t 4}
\end{aligned}
$$


From the above equations ( 3 to 6 ), $\Delta$ represents the first difference, while $\ln \mathrm{Q}, \ln \mathrm{K}, \ln \mathrm{L}$ and $\ln \mathrm{E}$ are the natural logarithms of production, capital, labour and energy, respectively. ect symbolize the error correction term. The coefficients $\theta_{\mathrm{n}}, \alpha_{\mathrm{n}}, \beta_{\mathrm{n}}$ and $\gamma_{\mathrm{n}}(n=0,1,2,3)$, indicate the short run causality if the value is not equal to zero. We also can determine the long run causality, using the null and alternative hypothesis, as mentioned above:-

$\mathrm{H}_{0}: \partial_{n}=0$, there is no long run causality.

$\mathrm{H}_{1}: \partial_{n} \neq 0$, there is long run causality. $\quad(n=0,1,2,3)$

\section{Results Analysis}

\subsection{Stationarity Test}

Table 1 presents the results of the ADF and PP tests. It shows that at conventional levels of significance, none of the variables represent a stationary process in their levels. When the variables were tested in first differences, the null hypothesis was rejected in the case of the ADF and PP tests except for the energy, stationary at second differences. Then, we conclude that the $\ln \mathrm{Q}, \ln \mathrm{K}$ and $\ln \mathrm{L}$ integrated of $I(1)$ at $1 \%$ and $5 \%$ level of significant, however in the case of the $\ln \mathrm{E}$ integrated of $I(2)$ at $1 \%$ significant level.

\subsection{Co-integration Test}

To verify if the variables under study are cointegrated, we proceed with the Cointegrating Regression Durbin Watson (CRDW), (Cromwell et al.,1994) technique.We begin with the estimation of the cointegrating regression between the variables (Equation 2). Then, estimate the Durbin Watson(DW) statistics for the cointegrating regression. The result shows that the DW statistics is less than the DF(Dicker-Fuller) or critical value at $1 \%$ level of significant. Therefore, this result indicates that there is a long run and dynamic relationship between the production, capital, labour and energy variables. Also, this result supports the production theory in terms of relationship between the production and capital, labour as well as energy variables.

\subsection{Vector Error Correction and Granger Causality}

As the variables are cointegrated, the Granger causality test within the VECM framework should be conducted (Tang, 2011). Therefore, the VECM would provide us with the evidence of short run and long run causality relationship (Bekhet \& Othman, 2011). The result as shown below in Equations (7 to 10):

$$
\begin{aligned}
& \Delta \ln Q_{t}=0.163-0.171 \Delta \ln Q_{t-1}-0.049 \Delta \ln K_{t-1}+0.191 \Delta \ln L_{t-1}-0.334 \ln E_{t-1}-0.421 e c t_{t-1} \\
& \mathrm{p} \text { value } \quad(0.00) \quad(0.65) \quad(0.78) \\
& \text { t-statistics (3.49) (-0.46) (-0.28) } \\
& (0.69) \quad(0.50) \\
& (0.39) \quad(-0.68) \\
& \mathrm{R}^{2}=0.14, \quad \mathrm{DW}=1.97, \quad \text { F-test }=0.79(0.56) \\
& \Delta \ln K_{t}=-0.015+0.308 \Delta \ln Q_{t-1}+0.102 \Delta \ln K_{t-1}+0.217 \Delta \ln L_{t-1}+0.168 \ln E_{t-1}-0.133 e c t_{t-1} \\
& \mathrm{p} \text { value } \quad(0.83) \quad(0.56) \\
& \text { t-statisitics }(-0.22) \quad(0.58)
\end{aligned}
$$

$\mathrm{R}^{2}=0.1996, \quad \mathrm{DW}=1.98, \mathrm{~F}$-test $=1.197(0.34)$

$$
\Delta \ln L_{t}=0.056-0.004 \Delta \ln Q_{t-1}-0.067 \Delta \ln K_{t-1}+0.315_{2} \Delta \ln L_{t-1}+0.21 \ln E_{t-1}-0.026 e c t_{t-1}
$$

$$
\begin{array}{llllllr}
\mathrm{p} \text { value } & (0.19) & (0.499) & (0.67) & (0.47) & (0.63) & (0.90) \\
\text { t-statistics } & (1.35) & (-0.686) & (-0.43) & (0.74) & (0.49) & (-0.12) \\
\mathrm{R}^{2}=0.05 \text {, DW }=2.04 \text {, F-test }=0.25(0.94) & &
\end{array}
$$

\begin{tabular}{lllllll}
\multicolumn{5}{c}{$\Delta \ln E_{t}=$} & $0.058-0.239 \Delta \ln Q_{t-1}+0.212 \Delta \ln K_{t-1}-0.014 \ln L_{t-1}+0.267 \ln E_{t-1}+0.205 e c t_{t-1}$ \\
$\mathrm{p}$ value & $(0.11)$ & $(0.395)$ & $(0.119)$ & $(0.97)$ & $(0.47)$ & $(0.27)$ \\
t-statistics & $(1.66)$ & $(-0.866)$ & $(1.62)$ & $(-0.04)$ & $(0.73)$ & $(1.13)$ \\
$\mathrm{R}^{2}=0.205, \mathrm{DW}$ & $=1.38, \mathrm{~F}$-test $=1.23(0.32)$
\end{tabular}

The results show that all exogenous variables are found to be insignificant in all equations. These results indicate that there are no short run causality between production and energy of industrial manufacturingin Malaysia. Although, in the long run causality, the result implied that there is uni-directional causality running from energy to 
production (Equation 4). This result indicates that the energy use in industrial manufacturingin Malaysia affects the production only for the long run period. Therefore, these analyses identify that energy use seems to play important role in the Malaysian industrial manufacturingonly in the long run period.

\section{Policy Implications}

The analysis shows that there is no short run causality between production and energy of industrial manufacturingin Malaysia. Soytas (2007) also found that the electricity consumption does not appear to be significant in any of the equations and thus, none of the variables appear to be significant in the electricity consumption in the Turkish manufacturing industrial.

Turning to the long run causality, the result implies that there is uni-directional causality running from energy to production. This result indicates that the energy use in industrial manufacturingin Malaysia affects the production only for the long run period. Similarly, Soytas (2007) also found uni-directional causality running from electricity consumption to manufacturing value added in Turkey. Ghaliand El Sakka (2004) found bi-directional causality between energy consumption and Canadian output.

Thus, this analysis specifies that the production of industrial manufacturing in Malaysia depends on the usage of energy.As it is well known, industrial manufacturinghas a large influence in the country's economy. In Malaysia, industrial manufacturingcontribute RM53,482 million out of RM202,986 (26\%) to the GDP (Bank Negara, 2011). Therefore, the impacts of energy use indirectly may increase the growth rate in Malaysia.

Even though, energy plays an important role in the production, usage of energy, however, creates some undesirable impacts on the environment and climate. Therefore, Malaysian government has introducedan alternative energy called renewable energy. There are many projects such as the Small Renewable Energy Power Programme (SREP) (Note 1) as well as current biomass utilization projects. These projects are very useful in the future as they provide vital information and plans to increase renewable energy.

The main aim of the SREP is to promote a wider use of the huge amount of RE resources available in Malaysia, particularly its utilization in power generation (Energy Commission). Instead of biomass, there are other of renewable energy such assolar energy, hydropower, wind energy and coal. All these resources are available and extracted from natural resources. Consequently, this alternative energy will be used for the manufacturing industrial, instead of oil and fuel.

\section{Conclusion and Recommendation}

The current paper examines the causal relationship between production and energy in the industrial manufacturing for the 1978-2009 period. It used production, capital, labour and energyas input variables. All these variables were transformed into a logarithms form.

To achieve the objective of this study, we employed the CRDW test for cointegration and also the Granger causality test within the VECM. Additionally, we used the ADF and PP tests to examine the stationarity of each variable. Results show that all variables are stationary of $I(1)$ at $1 \%$ and $5 \%$ significance level, except the energy which is stationary of $I(2)$ at $1 \%$ significance level.

The result for co-integration test shows that all variables are cointegrated at $1 \%$ significance level. There is no short run causality between production and energy of industrial manufacturingin Malaysia. Although in the long run, there is uni-directional causality running from energy to production. This result indicates that energy is an important factor affecting the production of industrial manufacturingin the long run period.

This paper should be extended in terms of methodology by using the Autoregressive-Distributed Lag (ARDL) estimation procedure. This procedure enables us to estimate the single cointegrating relation on the basis of an ARDL model selected by means of model selection procedures such as Akaike, Schwarz, Hannan and Quinn and $\mathrm{R}^{2}$. The broadened analysis will help other researchers and policy makers to sketch appropriate policies, particularly in the manufacturing industrial.

\section{References}

Asafu-Adjye, J. (2000). The relationship between energy consumption, energy prices and economic growth: time series evidence from Asian developing countries. Energy Economics, Vol. 22, pp. 615-625. http://dx.doi.org/10.1016/S0140-9883(00)00050-5

Bank Negara. (2007). BNM National Summary Data Page.Retrieved November 8.

Bekhet, H.A. (2009). Assessing Economic Connectedness Degree of the Malaysian Economy: Input-Output Model Approach. International Journal of Economic and Finance, Vol.1, No.2, pp.134-143. 
Bekhet, H.A. (2010). Ranking sectors changes of the Malaysian economy: Input-output approach. International Business Research, Vol.3, pp. 107-130.

Bekhet, H.A. (2011). Output, Income and Employment Multipliers in Malaysian Economy: Input-Output Approach, International Business Research, Vol.4, No.1,pp. 208-223.

Bekhet, H.A., \& Othman, N. (2011). Causality analysis among electricity consumption, consumer expenditure, gross domestic product (GDP) and foreign direct investment (FDI): Case study of Malaysia. Journal of Economics and International Finance, Vol. 3, pp. 228-235.

Belloumi, M. (2009). Energy consumption and GDP in Tunisia: Cointegration and causality analysis. Energy Policy, Vol. 37, pp. 2745-2753. http://dx.doi.org/10.1016/j.enpol.2009.03.027

Chandran, V.G.R., Sharma, S., \& Madhavan, K. (2010). Electricity consumption-growth nexus: The case of Malaysia. Energy Policy, Vol. 38, pp.606-612. http://dx.doi.org/10.1016/j.enpol.2009.10.013

Constantini, V., \& Martini, C. (2010). The causality between energy consumption and economic growth: A multi-sectoral analysis using non-stationary cointegrated panel data. Energy Economics, Vol. 32, pp. 591-603. http://dx.doi.org/10.1016/j.eneco.2009.09.013

Cromwell,J.B., Hannan, M.J., Labys,W.C., \& Terrazu, M. (1994). Multivariate tests for time series models. Sage University Paper Series on Quantitative Applications in The Social Sciences, series no. 07-100. Sage Publications, Inc., Thousand Oaks, California.

Energy Commission. http://www.st.gov.my

Ghali, K.H., \& El-Sakka, M.I.T. (2004). Energy use and output in Canada: a multivariate cointegration analysis. Energy Economics, Vol. 26, pp. 225-238. http://dx.doi.org/10.1016/S0140-9883(03)00056-2

http://www.nationsencyclopedia.com/economies/Asia-and-the-Pacific/Malaysia.html

http://www.treasury.gov.my

Jamil, F., \& Ahmad, E. (2010).The relationship between electricity consumption, electricity prices and GDP in Pakistan. Energy Policy, Vol. 38, pp. 6016-6025. http://dx.doi.org/10.1016/j.enpol.2010.05.057

Jumbe, C.B.L. (2004). Cointegration and causality between electricity consumption and GDP: empirical evidence from Malawi. Energy Economics, Vol. 26, pp. 61-68. http://dx.doi.org/10.1016/S0140-9883(03)00058-6

Lorde, T., Waithe, K., \& Francis, B. (2010).The importance of electrical energy for economic growth in Barbados. Energy Economics, Vol. 32, pp. 1411-1420. http://dx.doi.org/10.1016/j.eneco.2010.05.011

Mozumder, P., \& Marathe, A. (2007).Causality relationship between electricity consumption and GDP in Bangladesh. Energy Policy, Vol. 35, pp. 395-402. http://dx.doi.org/10.1016/j.enpol.2005.11.033

Narayan, P.K., \& Smyth, R. (2009). Multivariate granger causality between electricity consumption, exports and GDP: Evidence from a panel of Middle Eastern countries. Energy Policy, Vol.37, pp. 229-236. http://dx.doi.org/10.1016/j.enpol.2008.08.020

Sari, R., Ewing, B.T., \& Soytas, U. (2008). The relationship between disaggregate energy consumption and industrial production in the United States: An ARDL approach. Energy Economics, Vol.30, pp. 2302-2313. http://dx.doi.org/10.1016/j.eneco.2007.10.002

Shahbaz, M., Tang, C.F., \& Shabbir, M.S. (2011).Electricity consumption and economic growth nexus in Portugal using cointegration and causality approaches. Energy Policy, Vol. 39, pp. 3529-3536. http://dx.doi.org/10.1016/j.enpol.2011.03.052

Shiu, A., \& Lam, P.L. (2004). Electricity consumption and economic growth in China. Energy Policy, Vol. 32, pp. 47-54. http://dx.doi.org/10.1016/S0301-4215(02)00250-1

Soytas, U., \& Sari, R. (2003). Energy consumption and GDP: causality relationship in G-7 countries and emerging markets. Energy Economics, Vol. 25, pp. 33-37. http://dx.doi.org/10.1016/S0140-9883(02)00009-9

Soytas, U., \& Sari, R. (2007). The relationship between energy and production: Evidence from Turkish manufacturing industry. Energy Economics, Vol. 29, pp. 1151-1165. http://dx.doi.org/10.1016/j.eneco.2006.05.019

Stern, D. I. (1993). Energy and economic growth in the USA: A multivariate approach. Energy Economics, Vol. 15, pp. 137-149. http://dx.doi.org/10.1016/0140-9883(93)90033-N

Stern, D.I. (2000). A multivariate cointegration analysis of the role of energy in the US macroeconomy. Energy Economics, Vol. 22, pp. 267-283. http://dx.doi.org/10.1016/S0140-9883(99)00028-6 
Studenmund, A.H. (2006). Using Econmetrics: A Practical Guide.6th Edition.Pearson International Edition, USA.

Sweeney, J.L. (2000). Economics of Energy. Monograf.Vol. 4.9, pp. 0-28.

Tang, C.F. (2009). Electricity consumption, income, foreign direct investment, and population in Malaysia: New evidence from multivariate framework analysis. Journal of Economics Studies, Vol.36, pp. 371-382. http://dx.doi.org/10.1108/01443580910973583

Yang, H.Y. (2000). A note on the causal relationship between energy and GDP in Taiwan.Energy Economics, Vol. 22, pp. 309-317. http://dx.doi.org/10.1016/S0140-9883(99)00044-4

Ya-qun, H.E., Guo-hong, L., Chriss, E.O, Wei-ran, Z., \& Bao-feng, W. (2008). Co-integration based analysis of energy assurance for steady economic growth in China. Journal of China University of Mining \& Technology, Vol.18, pp. 250-254.

Zaini, N.A. Energy System (Alternative Energy for Malaysia), Work paper no. ESC4602. Faculty of Environmental Studies, Universiti Putra Malaysia (UPM), Selangor.

\section{Notes}

Note 1. launchedby the Government on 11th May 2001.

Table 1. Unit Root test for stationarity.

\begin{tabular}{|c|c|c|c|c|c|c|c|}
\hline \multirow{3}{*}{ Variables } & \multicolumn{2}{|c|}{ At Levels } & \multicolumn{2}{c|}{ At First difference } & \multicolumn{2}{c|}{ At Second difference } & \multirow{2}{*}{$\begin{array}{c}\text { Order of } \\
\text { Integration }\end{array}$} \\
\cline { 2 - 8 } & ADF & PP & ADF & PP & ADF & PP \\
\cline { 2 - 8 } & $\begin{array}{c}\text { Trend and } \\
\text { Intercept }\end{array}$ & $\begin{array}{c}\text { Trend and } \\
\text { Intercept }\end{array}$ & $\begin{array}{c}\text { Trend and } \\
\text { Intercept }\end{array}$ & $\begin{array}{c}\text { Trend and } \\
\text { Intercept }\end{array}$ & $\begin{array}{c}\text { Trend and } \\
\text { Intercept }\end{array}$ & $\begin{array}{c}\text { Trend and } \\
\text { Intercept }\end{array}$ & \\
\hline $\ln Q$ & -2.312476 & -2.408096 & $-5.910220^{*}$ & $-5.936686^{*}$ & $-6.290390^{*}$ & $-28.69360^{*}$ & $I(1)$ \\
\hline $\ln \mathrm{N}$ & -2.322537 & -1.898508 & $-3.777836^{* *}$ & $-3.636330^{* *}$ & $-5.457542^{*}$ & $-12.85993^{*}$ & $I(1)$ \\
\hline $\ln \mathrm{L}$ & -1.661612 & -1.954236 & $-4.869660^{*}$ & $-4.906671^{*}$ & $-6.764765^{*}$ & $-11.62940^{*}$ & $I(1)$ \\
\hline $\ln \mathrm{E}$ & -0.855234 & -1.174737 & -2.617604 & -2.486365 & $-6.110960^{*}$ & $-6.210882^{*}$ & $I(2)$ \\
\hline
\end{tabular}

Notes: *it means that the value test less $(<)$ than critical value at $1 \%$.

$* *$ it means that the value test less $(<)$ than critical value at $5 \%$.

$* * *$ it means that the value test less $(<)$ than critical value a $10 \%$.

Source : Output Eviews 6.0

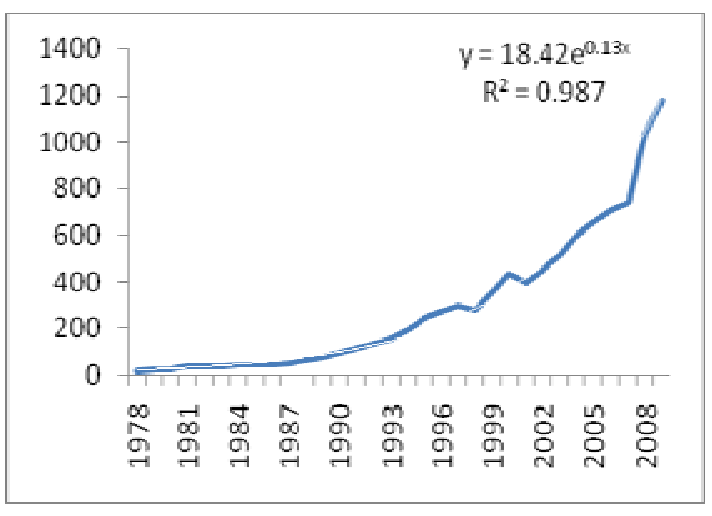

Source: Department of Statistics, Malaysia (2009)

Figure 1. Production of industrial manufacturing for 1978-2009 (RM million)

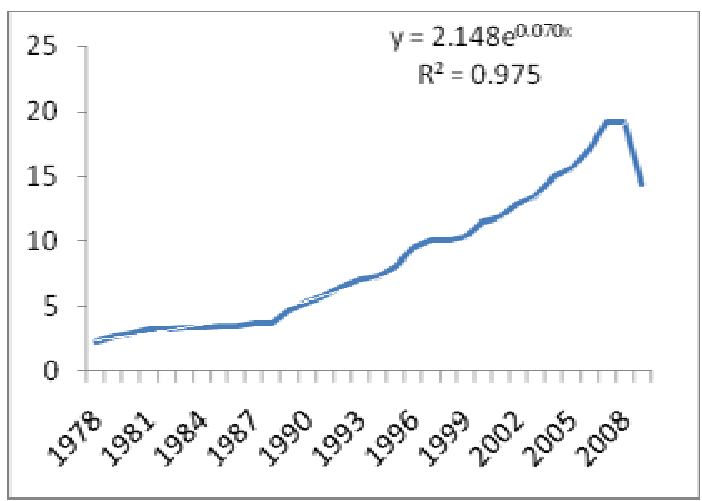

Source :Department of Statistics, Malaysia (2009) Figure 2. Total energy use in industrial manufacturing for 1978-2009 (ktoe`000) 


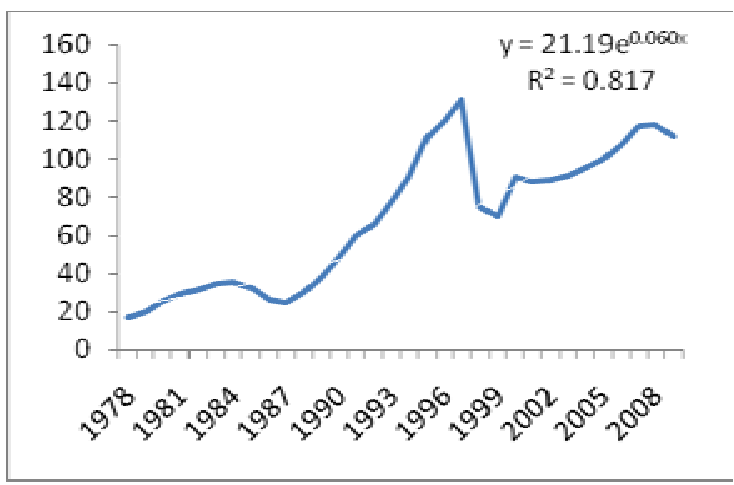

Source: Department of Statistics, Malaysia (2009) Figure 3. Capital ofindustrial manufacturing in for 1978-2009 (RM’000)

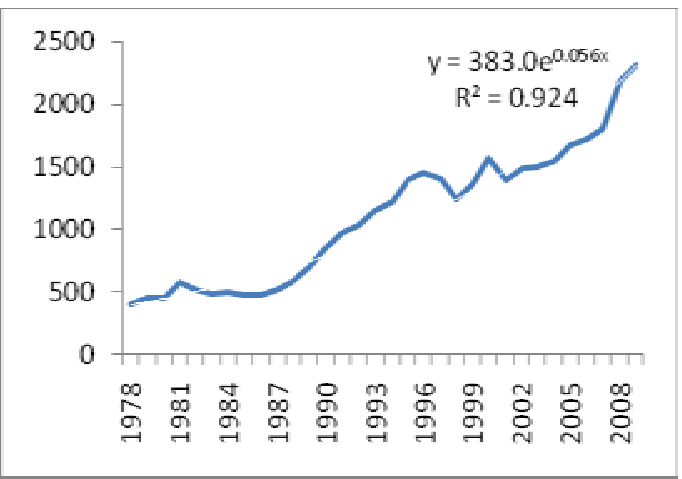

Source: Department of Statistics, Malaysia (2009)

Figure 4. Number of workers in industrial manufacturing for 1978-2009 ('000) 